Materiales de Construcción

Vol. 69, Issue 334, April-June 2019, e188

ISSN-L: 0465-2746

https://doi.org/10.3989/mc.2019.04118

\title{
Petrophysical-mechanical behavior of Grisolia stone found in the architectural heritage of southern Italy
}

\author{
G. Forestieri ${ }^{\mathrm{a}} \bowtie$, M. Alvarez de Buergo ${ }^{\mathrm{b}}$ \\ a. Facultad de Ingeniería, Universidad de la Sabana, Campus Universitario del Puente del Común, (Chía, Cundinamarca, Colombia) \\ b. Instituto de Geociencias IGEO (CSIC-UCM). Consejo Superior de Investigaciones Científicas - \\ Universidad Complutense de Madrid, (Madrid, Spain) \\ $\triangle$ giulia.forestieri@unisabana.edu.co
}

Received 18 April 2018 Accepted 27 November 2018 Available on line 04 April 2019

\begin{abstract}
Grisolia is one of the building stones most commonly found in the architectural heritage of southern Italy. Also known commercially as "gold stone" for its yellow intrusions, Grisolia was employed by the leading Calabrian schools of stonemasons, principally in the southern Italian regions of Calabria and Basilicata. It is an Upper Triassic crystalline carbonate quarried in the Verbicaro Unit on Calabria's northern Tyrrhenian coast.

Possessing petrographic, physical and mechanical properties that ensure stone strength and durability, it is a high-quality building material suitable for structural and ornamental uses. These properties can be attributed to its low open porosity and excellent hydric behavior (low capillary water absorption), as well as to its high mechanical strength and low anisotropy. These characteristics make it recommendable as a building material for both restoration and new construction.
\end{abstract}

KEYWORDS: Limestone; Characterization; Physical properties; Mechanical properties.

Citation/Citar como: Forestieri, G.; Álvarez de Buergo, M. (2019) Petrophysical-mechanical behavior of Grisolia stone found in the architectural heritage of southern Italy. Mater. Construcc. 69 [334], e188 https://doi.org/10.3989/ mc.2019.04118

RESUMEN: Comportamiento petrofísico-mecánico de la piedra de Grisolia del patrimonio arquitectónico del sur de Italia La "piedra de Grisolia" es una de las piedras de construcción más utilizadas en el patrimonio arquitectónico del sur de Italia. También conocida comercialmente como "piedra de oro" por su color dorado, fue empleada por las más importantes escuelas de cantería, principalmente en las regiones italianas del sur, Calabria y Basilicata. Se trata de un carbonato cristalino del Triásico Superior extraído en la Unidad Verbicaro, en la costa Tirrénica del norte de Calabria.

Gracias a sus propiedades petrográficas, físicas y mecánicas que aseguran su resistencia y durabilidad, es un material de alta calidad adecuado para fines estructurales y ornamentales. Estas propiedades se deben a su baja porosidad, excelente comportamiento hídrico - baja absorción capilar -, así como a su alta resistencia mecánica y baja anisotropía. Gracias a esas buenas propiedades, se recomienda su empleo como material de construcción tanto para la recuperación de edificios antiguos así como para la construcción de obra nueva.

PALABRAS CLAVE: Caliza; Caracterización; Propiedades físicas; Propiedades mecánicas.

ORCID ID: G. Forestieri (https://orcid.org/0000-0003-2557-8637); M. Álvarez de Buergo (https://orcid. org/0000-0002-7520-2390)

Copyright: (C) 2019 CSIC. This is an open-access article distributed under the terms of the Creative Commons Attribution 4.0 International (CC BY 4.0) License. 


\section{INTRODUCTION}

For centuries, Grisolia stone (DG) has been used as a building material both in the towns of the Upper Tyrrhenian part of Calabria (particularly in the province of Cosenza) and throughout the historic centers of the neighboring Basilicata region (1).

This stone has long been employed not only in vernacular construction in the above-mentioned towns, but also in construction of the major religious and aristocratic buildings that form part of Calabria's architectural heritage. One of the foremost of these is the church of San Francesco (14th century) in Aieta, in which Grisolia stone provides the main building material. Other examples of aristocratic Calabrian architecture are the famous Principi Spinelli (13th century) and MartiranoSpinelli (14th century) palaces (Figure 1) in Scalea and Aieta, respectively. Grisolia stone has been employed for both decorative purposes (elements of palace façades and portals) and structural uses (masonry, arches and retaining walls).

Over the centuries, this building material has been quarried extensively and, in the Pollino and coastal Tyrrhenian ranges in particular, this lithology has also been used to produce artificial stone. Commercially, Grisolia stone, also known as "gold stone" for its yellow intrusions (2), which are visible to the naked eye and are probably due to impurities, was also used as a "comparing stone" to judge the purity of silver or gold.

Macroscopically, Grisolia stone is a compact, deep-grey limestone. The stone varieties differ only in slight variations in tone, which ranges from dark grey to greenish bronze.

Due to Grisolia stone's historical and architectural importance, several authors have studied it extensively from a geological point of view (3-6). Nevertheless, complete petrophysical and mechanical characterization has not yet been performed. This paper focuses on complete characterization of this stone in order to highlight its properties and encourage its use as a building stone in both conservation of heritage and construction of new buildings.

\section{GEOLOGICAL SETTING}

Geologically, Grisolia stone is part of the carbonatic deposits of the Upper Triassic found in the Verbicaro Unit $\left(39^{\circ} 45^{\prime} \mathrm{N}\right.$ and $\left.15^{\circ} 54^{\prime} \mathrm{E}\right)$ (3) (Figure 2). These deposits are also referred to as "Trias Dolomitique" (7) or "dark dolostones" (4). The upper part of the Verbicaro Unit, which corresponds to the Grisolia Formation, is characterized by a succession of grey limestones alternating with yellowish/reddish argillites and marls (5). The Grisolia Formation extends from the Lao river to Papasidero, with outcrops found in the Serra la Limpida mountains and between the Lao river and the road that connects Santa Domenica Talao to Papasidero.

It is considered a transitional stone positioned between dark dolostone and grey limestone and has an average thickness of 50-60 m (4). The Grisolia Formation is composed of clayschists, quartzarenites and crystalline carbonates that are dark grey in color and contain microfossils (5).

In the Verbicaro Unit, Grisolia stone was traditionally quarried in large blocks for ornamental use, while other limestones and dolostones were mainly used for aggregates. Although quarries were scattered throughout the area bounded by the towns of S. Maria del Cedro, Grisolia, Cetraro, Guardia Piemontese, Fuscaldo, Paola, San Lucido and Belmonte Calabro, most of the stone was quarried within the municipal districts of Verbicaro and Grisolia.

\section{METHODS}

Petrophysical, mineralogical and mechanical characterization of the crystalline carbonates taken from the active Anania quarry $\left(39^{\circ} 43^{\prime} \mathrm{N}\right.$ and $15^{\circ} 51^{\prime} \mathrm{E}$ ) (Figure 3 ) were carried out on a set of specimens collected at two different levels of the quarry in Grisolia. Characterization was performed
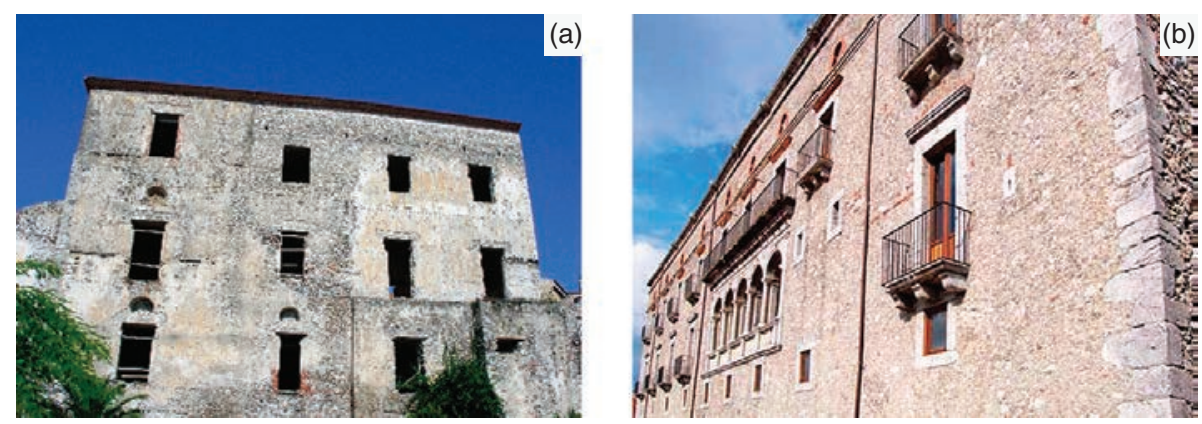

Figure 1. "Spinelli's Prince Palace" of the $13^{\text {th }}$ century in Scalea and "Martirano-Spinelli Palace" of the $14^{\text {th }}$ century in Aieta, southern Italy, built with Grisolia stone. 


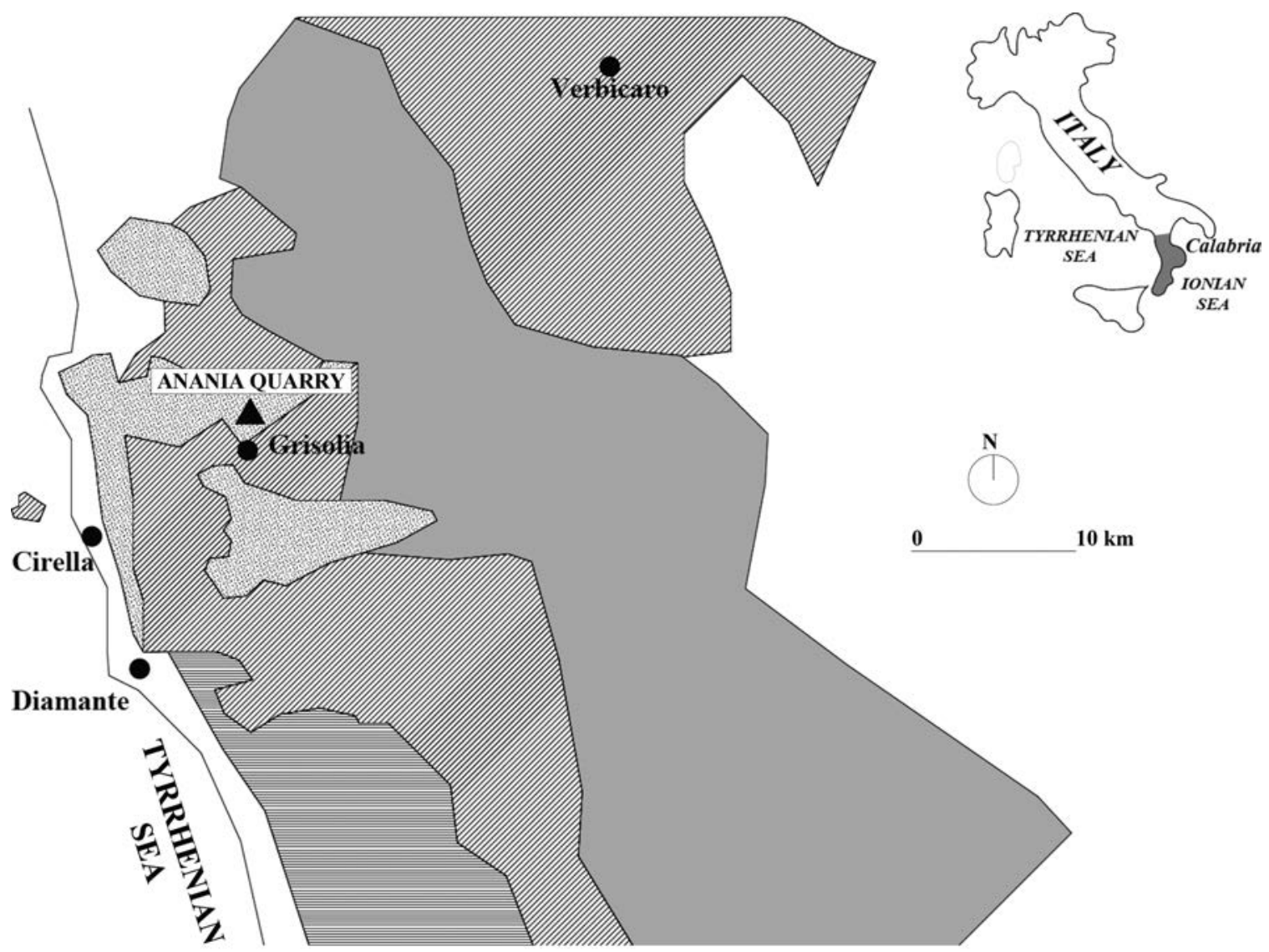

\section{Sediments (Quaternary)}

Marine deposits (Pliocene)

Miocenic deposits (Miocene)

Frido Formation - Verbicaro Unit (Upper Triassic-Cretaceous)

Serra Bonangelo Formation (Jurassic)

FIGURE 2. Geological sketch map of Verbicaro Unit of the Upper Triassic and localization of "Anania quarry" in Grisolia, southern Italy.
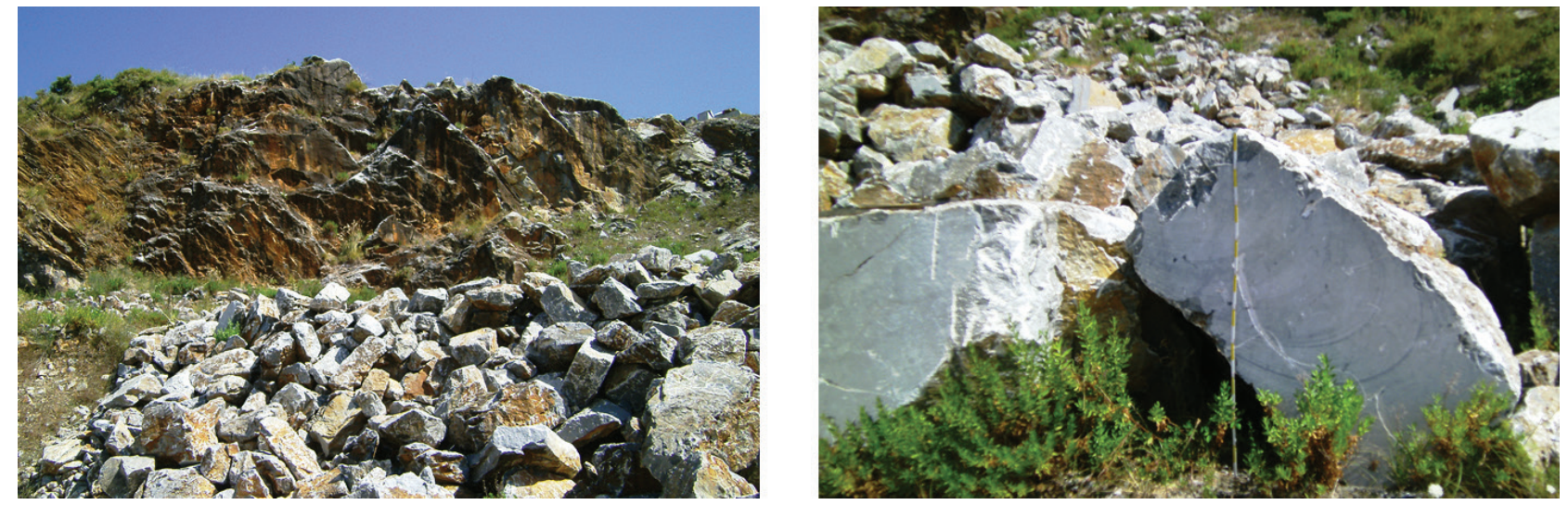

FiguRE 3. Active quarry "Anania" in Grisolia, southern Italy. 
on two blocks per level, taking into account the macroscopic features.

Quarry blocks were cut with a diamond cutting wheel to obtain specimens with shapes and dimensions specific to each test. Specimens were labelled with the letters "DG" (indicating "Grisolia dolostone") and were numbered in ascending order (4). For each sample, splitting planes were determined in the quarry according both to the coordinate reference system established for the three orthogonal directions (X, Y and $\mathrm{Z}$ ) and to stratification.

The number of samples used for each analysis was set according to the existing European standard (EN). Thin sections for petrographic analysis (8) were cut according to the splitting planes, considering the anisotropy of the rock (one thin section was cut along the XY quarry plane and the other two, perpendicular to the first one, were cut along the $\mathrm{YZ}$ and the XZ planes, respectively) (Figure 4a).

Specimen lengths were measured in the three orthogonal directions with a Mitutoyo digital caliper with a precision of $\pm 0.01 \mathrm{~mm}$. Measurements were taken in each of the three orthogonal directions and averaged.

Petrographic analysis was performed on uncovered and polished thin sections using an Olympus BX 51 polarized light microscope (PM) fitted with a DP 12-coupled camera. Analysis aimed to identify primary minerals and to describe stone samples in petrographical terms. A mineralogical study of the samples was conducted using X-Ray Diffraction (XRD) analysis. The XRD analysis was carried out using a Bruker diffractometer (D8 Advance) coupled to a copper tube. The diffractograms obtained were studied using qualitative and quantitative analysis software (PC-ADP DIFFRACTION).

Physical-mechanical characterization was performed using analytical methodologies: mercury intrusion porosimetry (MIP), chromatic analysis, capillary water absorption test, ultrasonic pulse velocity test (UPV), uniaxial compressive strength test (UCS) and flexural strength test (FST).

Pore diameter distribution, total cumulative mercury volume, average pore diameter and open porosity were determined by MIP. This test, performed using a Micromeritics Autopore IV mercury porosimeter, furnished information about pore specific surface and apparent and skeletal density. Regarding pore size, the Ordaz and Esbert classification for stone decay (9) was used, which differentiates between micropores $(<7.5 \mu \mathrm{m})$ and macropores $(>7.5 \mu \mathrm{m})$. Nine prismatic samples measuring $0.5 \times 0.5 \times 0.8 \mathrm{~cm}$ were prepared for MIP analysis.

Chromatic analysis was carried out on the surface specimens with the aid of a spectrophotometer (Minolta CM-700d) and Color Data Spectramagic TM NX CM-S100W software to obtain the color parameters for the CIE $1976 \mathrm{~L}^{*} \mathrm{a} * \mathrm{~b}^{*}$ system $\left(\mathrm{L}^{*}=\right.$ lightness; $\mathrm{a}^{*}=$ green $/$ red coordinates; $\mathrm{b}^{*}=$ blue/yellow coordinates; $\mathrm{C}^{*}=$ chroma parameter; the function of the $\mathrm{a}^{*}$ and $\mathrm{b}^{*}$ values is given

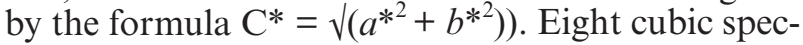
imens of $50 \mathrm{~mm}( \pm 5 \mathrm{~mm})$ per side were used for chromatic analysis (10). Thirty readings were taken from each cubic specimen (five readings per cube face) in order to provide an average representative result.

The same eight cubic specimens of $50 \mathrm{~mm}$ ( $\pm 5 \mathrm{~mm}$ ) per side employed for the non-destructive chromatic analysis were used for the capillary water absorption (11), UPV (12) and UCS tests (13).

The capillary water absorption test was carried out on cubic specimens aligned in the two anisotropic directions ( $\mathrm{X}$ and $\mathrm{Z}$ ). Specimens were placed in water of a depth of $3 \mathrm{~mm}( \pm 1 \mathrm{~mm})$ and the weight increase due to water absorption was measured at the time intervals stipulated in the corresponding standards until constant mass was reached (11) (Figure 4b). In order to describe the capillary water absorption behavior of the material, capillary coefficients parallel and perpendicular to the stratification planes (X and Z, respectively, obtaining $\mathrm{C}_{2}$ and $\mathrm{C}_{1}$, respectively) and the average coefficient $\mathrm{Cc}$ were evaluated according to the Snethlage classification (14). The stones were then classified as "slightly absorbing" ( $\mathrm{Cc}<8 \mathrm{~g} / \mathrm{m}^{2} \mathrm{~s}^{0.5}$ ), "medium absorbing" (Cc $\left.<8-50 \mathrm{~g} / \mathrm{m}^{2} \mathrm{~s}^{0.5}\right)$ or "highly absorbing" $\left(\mathrm{Cc}>80 \mathrm{~g} / \mathrm{m}^{2} \mathrm{~s}{ }^{0.5}\right)$. Water-related properties and (a)

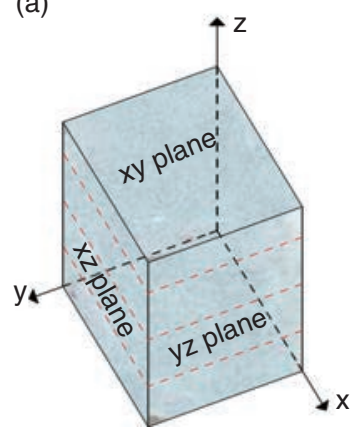

(b)

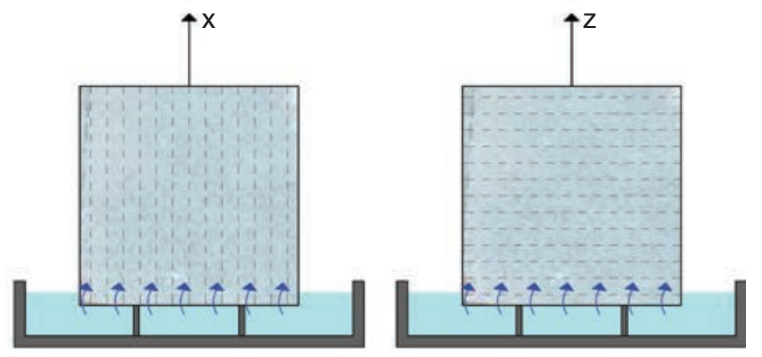

FIGURE 4. Schematic representation of splitting planes (a) and capillary water absorption test along the $\mathrm{X}$ and $\mathrm{Z}$ direction (b). 
parameters provide an insight into the behavior of the stone when exposed to the action of fluids, in particular water, and can be used to predict the stone's propensity to decay in the future (15).

The UPV values were obtained to an accuracy of 0.1 microseconds using the portable, non-destructive MATEST Meter Ver equipment fitted with two $55-\mathrm{kHz}$ frequency transducers (diameter of $1.5 \mathrm{~cm}$ ). During measurement, in order to improve coupling of the transducers (transmitter and receiver) to the surface of the stone substrate, a Farnell ultrasound couplant gel was applied to the opposing faces of the cubic samples. Direct mode was used, placing both transducers in parallel and on opposite sides of the specimens. UPV determination was performed in each of the three orthogonal directions - X, Y and $\mathrm{Z}$ - of the cubic specimens in order to analyze the spatial variation of the UPV. The anisotropy indices were also evaluated (16): total anisotropy ( $\left.\mathrm{dM}_{\mathrm{UPV}} \%\right)$ - using the three directions - and relative or bidimensional anisotropy $\left(\mathrm{dm}_{\mathrm{UPV}} \%\right)$. Five measurements were taken in each of the three orthogonal directions and averaged (12).

UCS (13) was performed using the MFL SYSTEM testing machine at a constant speed of $1 \mathrm{~mm} / \mathrm{min}$ and a maximum load capacity of $3000 \mathrm{~kg}$. UCS under unconfined conditions was performed in the three spatial directions: $\mathrm{X}, \mathrm{Y}$, and $\mathrm{Z}$. The corresponding $\mathrm{UCS}_{\max , \mathrm{X}}, \mathrm{UCS}_{\max , \mathrm{Y}}$, and $\mathrm{UCS}_{\max , \mathrm{Z}}$ values were calculated as the ratio between the maximum applied compressive load at failure and the cross-sectional area of the tested specimens. The $\mathrm{UCS}_{\text {mean }}$ value, characteristic of each stone type, was calculated as the average value (17) and the strength anisotropy was evaluated as the ratio of $\mathrm{UCS}_{\max } / \mathrm{UCS}_{\min }$.

For the FST, the three-point-load bending test was performed. For each direction, eight parallelepiped specimens measuring $300 \times 50 \times 50 \mathrm{~mm}$ $( \pm 5 \mathrm{~mm})$ were loaded to failure using an INSTRON 1195 testing machine at a maximum load capacity of $5000 \mathrm{~kg}$ and at a constant speed of $1 \mathrm{~mm} / \mathrm{min}$. For each specimen, the test was performed along the three splitting planes. The FST value of each sample was calculated according to current standards (18). In addition, the anisotropic FST index was evaluated as the ratio of the maximum and minimum values within the three spatial directions.

The mechanical strength values were compared against the Anon classification $(19,20,21)$, classifying stones as "moderately strong" (UCS of 12.5-50 MPa), "strong" (UCS of 50-100 MPa), "very strong" (UCS of 100-200 MPa) and "low" (FST of < 5 MPa), "moderate" (FST of 5-10 MPa), "high" (FST of 10-15 MPa) and "very high" (FST of $>15 \mathrm{MPa}$ ) to define the quality of the building stone.

\section{RESULTS}

\subsection{Petrographic and mineralogical characterization}

Petrographically, Grisolia stone was revealed to be a compact limestone with very low porosity. It showed a non-recognizable depositional texture and an intense level of diagenesis. It could be classified as a "crystalline carbonate" (22). Although it was fine-grained, it showed coarser calcite crystals near the veins. Its microstructure was very dense and no porosity was detected under the optical microscope (Figure 5).

The diagenetic process - due to recrystallization - could be related to neomorphism, in particular to aggrading neomorphism, which provoked formation of coarser crystalline mosaics (23). The micritic matrix was replaced by a neomorphic pseudosparite (crystal size of between 10 and $50 \mu \mathrm{m}$ ), distinguishable by the irregular distribution of the granulometry composed of coarse mosaics and finegrained areas.

Analysis of the thin sections in the three directions ( $\mathrm{X}, \mathrm{Y}$ and $\mathrm{Z}$ ) did not reveal any significant differences, at least at this microscopic level and considering the reduced area analyzed in the thin sections. In this crystalline limestone, diagenesis was governed by recrystallization and cementation
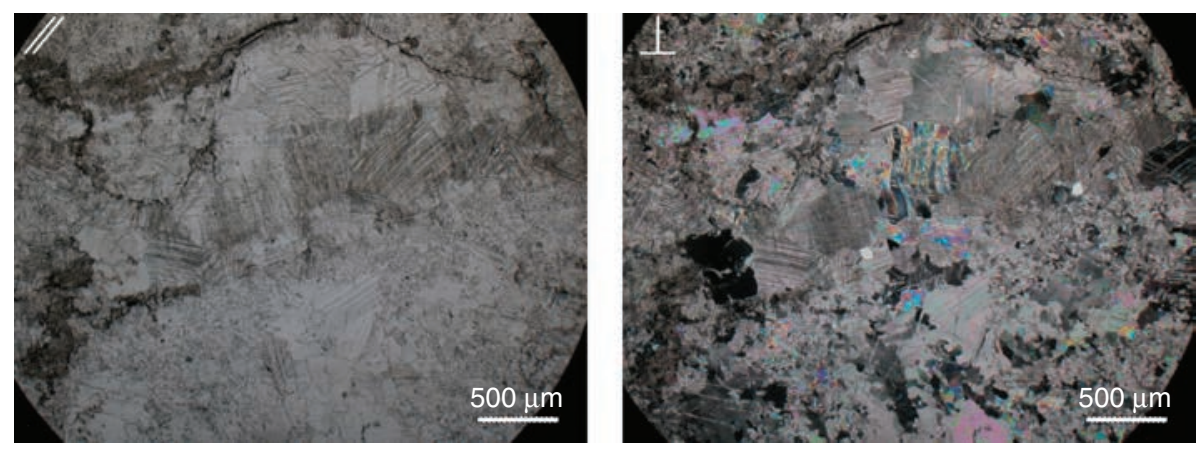

FIGURE 5. Micrographs under the polarized optical microscope of the analyzed thin sections of Grisolia stone, parallel $(/ /)$ and crossed nicols $(\perp)$, from left to right, respectively. 
processes that eliminated primary (inter- and intraparticle) porosity and generated secondary porosity in which the pore size distribution was homogeneous and the pores were partially sealed as a result of later cementation, as occurred in limestones and calcarenites (24).

The XRD results revealed that calcite is the main mineral. Dolomite was detected only in very small amounts.

\subsection{Physical-mechanical characterization}

The MIP results and colorimetric values obtained are given in Table 1. Skeletal and bulk densities were very similar and typical of carbonate rocks containing calcite in particular (14). The porosity was probably due to the presence of secondary fissures (14), as demonstrated by the low open porosity $\left(\mathrm{p}_{\mathrm{o}}\right)$ and the high compactness index (defined as the ratio between real density and bulk density). Average pore diameter corresponded to the range of macroporosity $(76 \%)(8)$ with a unimodal distribution (Figure 6). These low porosity values were similar to stones with a crystalline texture such as granite and marble and were lower than ornamental limestones $(24,25,26)$.

The chromatic parameters revealed Grisolia stone to be homogeneous (due to the low standard deviations) (Table 1).

The capillary water absorption coefficients obtained were, respectively, $1.22+0.12 \mathrm{~g} / \mathrm{m}^{2} \mathrm{~s}^{0.5}$ for $\mathrm{C} 1$ and $1.29+0.22 \mathrm{~g} / \mathrm{m}^{2} \mathrm{~s}^{0.5}$ for $\mathrm{C} 2$ corresponding to the "slightly absorbing" stone classification (14). Capillary water absorption was found to be very low, a common characteristic in highly compact crystalline stones (Figure 7). Analyzing capillary absorption revealed how the stone's hydric behavior was quite similar in the two directions studied, demonstrating

TABLE 1. Physical parameters obtained by MIP test: skeletal density $\left(\rho_{\mathrm{sk}}\right)$ and bulk density $\left(\rho_{\mathrm{b}}\right)$ in $\mathrm{kg} / \mathrm{m}^{3}$; open porosity to mercury $\left(\mathrm{p}_{\mathrm{o}}\right)$ in \%; compactness index $\left(\mathrm{I}_{\mathrm{c}}\right)$ in \%; average pore diameter $(\mathrm{D})$ in $\mu \mathrm{m}$. Chromatic parameters: $\mathrm{L}^{*}=$ lightness; $\mathrm{a}^{*}=$ green/red coordinate; $\mathrm{b}^{*}=$ blue/yellow coordinate; $\mathrm{C}^{*}=$ chroma

\begin{tabular}{lrrrrrrrrr}
\hline & $\rho_{\text {sk }}$ & $\rho_{\mathbf{b}}$ & $\mathbf{p}_{\mathbf{o}}$ & $\mathbf{I}_{\mathbf{c}}$ & $\mathbf{D}$ & $\mathbf{L}^{*}{ }_{(\mathbf{D} 65)}$ & $\mathbf{a}^{*}{ }_{(\mathbf{D} 65)}$ & $\mathbf{b}^{*}{ }_{(\mathbf{D} 65)}$ & $\mathbf{C}^{*}{ }_{(\mathbf{D} 65)}$ \\
\hline mean value & 2720 & 2700 & 0.54 & 0.99 & 0.70 & 71.27 & -0.24 & -1.38 & 1.96 \\
st.dev. & 101 & 110 & 0.08 & 0.01 & 0.03 & 1.11 & 0.16 & 1.45 & 0.48 \\
\hline
\end{tabular}

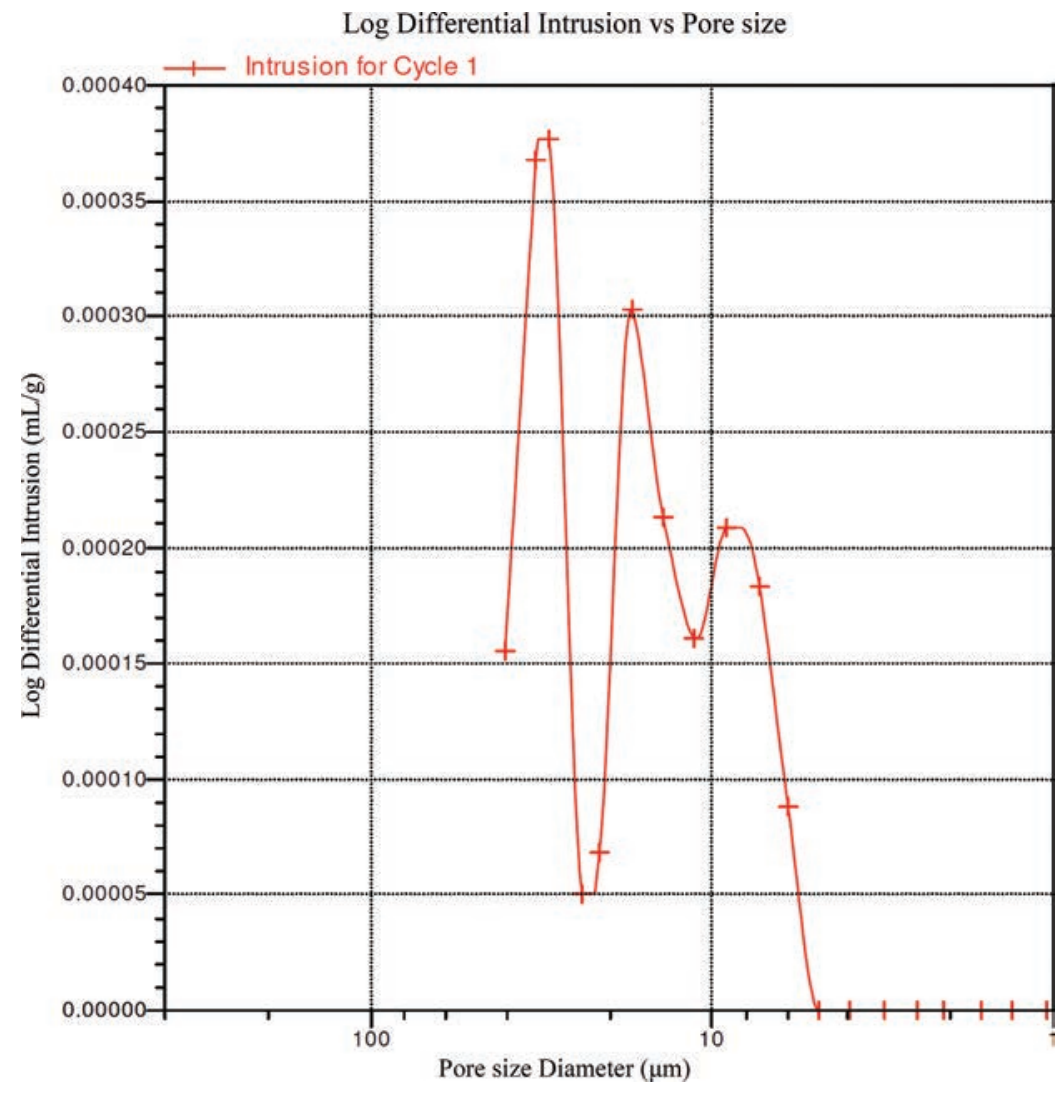

FIGURE 6. Pore size distribution curves [Log differential intrusion $(\mathrm{mL} / \mathrm{g})$ vs. pore size diameter $(\mu \mathrm{m})]$ obtained by MIP analysis. 
an isotropic hydric absorption trend. Moreover, macropores, which are often found in limestones like DG and were detected by MIP, influenced water absorption capability and aided water evaporation (14). The results of the hydric tests were directly related to the stone texture formed during the diagenesis stage.

UPV was used to find the absolute and relative anisotropy indices. The anisotropy values obtained (Table 2) were considerably lower than those reported for other carbonate stones $(27,28)$. UPV values in the three directions (X, Y and $\mathrm{Z}$ ) were very similar and indicative of DG's low anisotropy. Moreover, the high UPV values demonstrated the high compactness of the stone and were related to the "high velocity class". UPV depended largely on stone characteristics such as mineralogical composition, porosity and fracture density (29). The high UPV values observed were indicative of DG's high dynamic quality $(30,31)$.

Under mechanical stress, DG proved to be fragile. Young's modulus (E), determined from the stressstrain curves, depended slightly on the orientation of the specimen with respect to the bedding plane.
E values ranged from $83 \mathrm{GPa}$ to $85 \mathrm{GPa}$ (Table 3) and were higher when compared to similar resistant limestones (15). The respective Poisson coefficients (v) varied from 0.34 to 0.35 , with the highest value registered when the force was applied perpendicularly to the bedding plane. The values for the three orthogonal directions presented few differences, corroborating the low total anisotropy value obtained above. UCS values presented slight differences in the three spatial directions. This fact was in agreement with the low anisotropy ratio, DG's homogeneous features and its ultrasonic isotropic behavior. The maximum value of UCS was recorded along the $\mathrm{Z}$-axis, the intermediate value was recorded along the Y-axis and the minimum value was recorded along the $\mathrm{X}$-axis, with the averaged value corresponding to "strong" stone. The stress-strain curves in unconfined state (Figure 8) for the two directions analyzed showed that the behavior of the stone samples was almost quasi-linear elastic until failure. Graphically, the initial tangent modulus (i.e. the slope of the initial part of the stress-strain curve) remained almost equal to the tangent modulus at

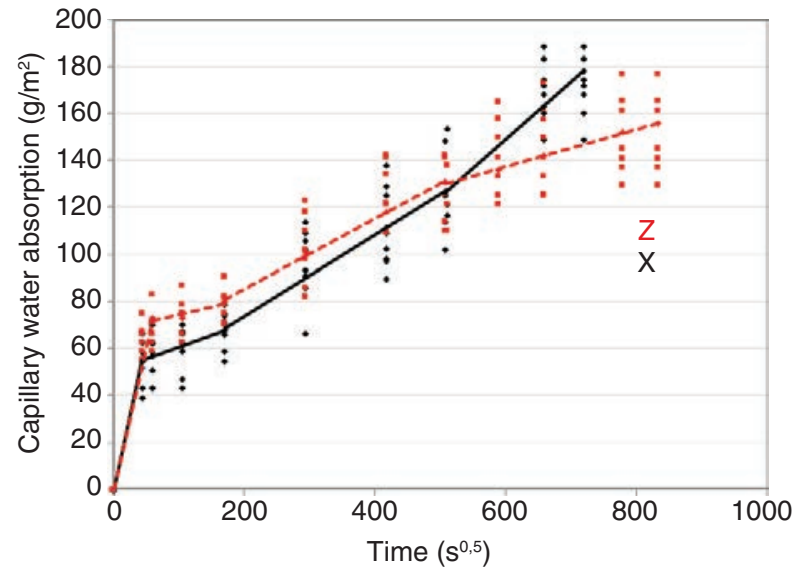

Figure 7. Capillary water absorption curves along the $\mathrm{X}$ and $\mathrm{Z}$ directions.

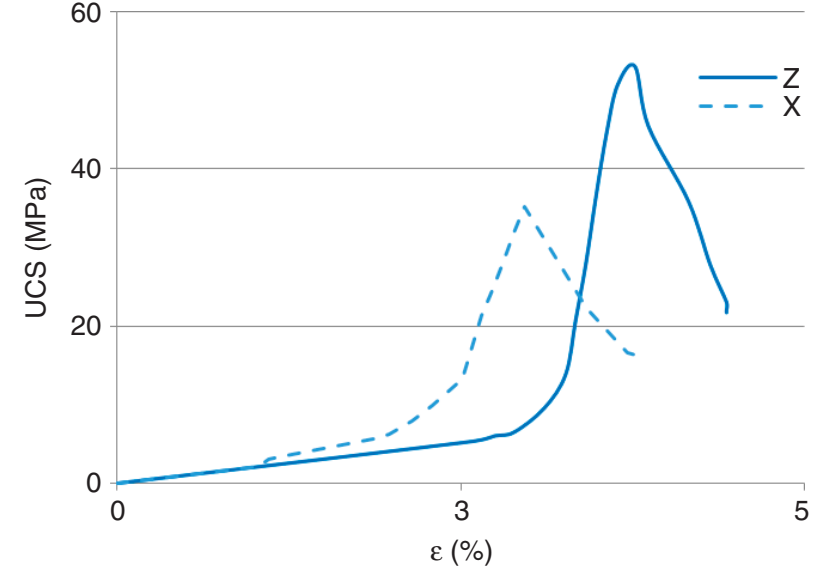

FIGURE 8. Stress-strain curve under UCS unconfined conditions, along the $\mathrm{X}$ and $\mathrm{Z}$ directions.

TABLE 2. $\mathrm{UPV}_{\mathrm{x}}, \mathrm{UPV}_{\mathrm{y}}, \mathrm{UPV}_{\mathrm{z}}=$ ultrasonic pulse velocity $(\mathrm{m} / \mathrm{s})$ recorded in the $\mathrm{X}, \mathrm{Y}$ and $\mathrm{Z}$ directions, respectively; UPV= average ultrasonic pulse velocity $(\mathrm{m} / \mathrm{s}) ; \mathrm{dM}_{\mathrm{UPV}} \%=$ total anisotropy index; and $\mathrm{dm}_{\mathrm{UPV}} \%=$ relative anisotropy index.

\begin{tabular}{lcccccc}
\hline & $\mathbf{U P V}_{\mathbf{X}}(\mathbf{m} / \mathbf{s})$ & $\mathbf{U P V}_{\mathbf{Y}}(\mathbf{m} / \mathbf{s})$ & $\mathbf{U P V}_{\mathbf{Z}}(\mathbf{m} / \mathbf{s})$ & $\mathbf{U P V}(\mathbf{m} / \mathbf{s})$ & $\mathbf{d M}_{\mathbf{U P V}}(\mathbf{\%})$ & $\mathbf{d m}_{\mathbf{U P V}}(\%)$ \\
\hline mean value & 6633 & 6600 & 6542 & 6592 & 1.1 & 0.5 \\
st.dev. & 56 & 76 & 73 & 76 & 0.5 & 0.5
\end{tabular}

TABLE 3. $\mathrm{E}_{\mathrm{x}}, \mathrm{E}_{\mathrm{y}}, \mathrm{E}_{\mathrm{z}}=$ Young's modulus $(\mathrm{GPa}) ; v_{\mathrm{x}}, v_{\mathrm{y}}, \mathrm{v}_{\mathrm{z}}=$ Poisson coefficient recorded in the directions $\mathrm{X}, \mathrm{Y}$ and $\mathrm{Z}$, respectively; $\mathrm{UCS}_{\mathrm{x}}, \mathrm{UCS}_{\mathrm{y}}, \mathrm{UCS}_{\mathrm{z}}=$ uniaxial compressive strength $(\mathrm{MPa})$ and; UCS = average uniaxial compressive strength $(\mathrm{MPa})$; and max/ $\min =$ anisotropy UCS strength ratio.

\begin{tabular}{|c|c|c|c|c|c|c|c|c|c|c|c|}
\hline & $\mathbf{E}_{\mathbf{X}}$ & $\mathbf{E}_{\mathbf{Y}}$ & $\mathbf{E}_{\mathbf{Z}}$ & $v_{X}$ & $v_{Y}$ & $v_{\mathrm{Z}}$ & $\mathbf{U C S}_{\mathbf{X}}$ & $\mathbf{U C S}_{\mathbf{Y}}$ & $\mathbf{U C S}_{\mathbf{Z}}$ & UCS & $\max / \min$ \\
\hline mean value & 83 & 84 & 85 & 0.34 & 0.34 & 0.35 & 60 & 64 & 65 & 63 & 1.1 \\
\hline st.dev. & 1 & 2 & 1 & 0.01 & 0.02 & 0.01 & 2 & 1 & 2 & 2 & \\
\hline
\end{tabular}


(a)

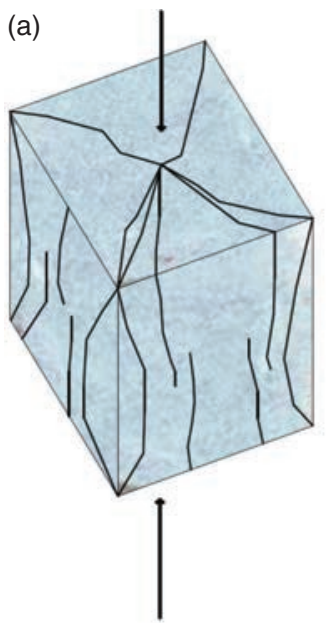

(b)

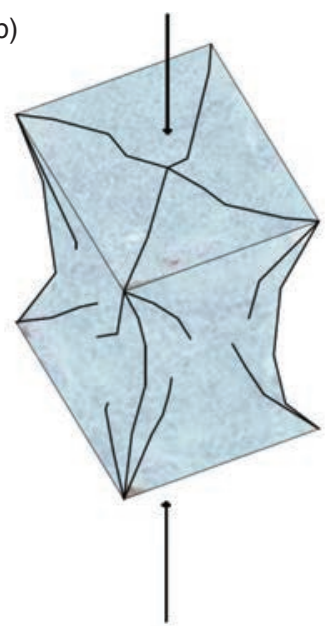

(c)

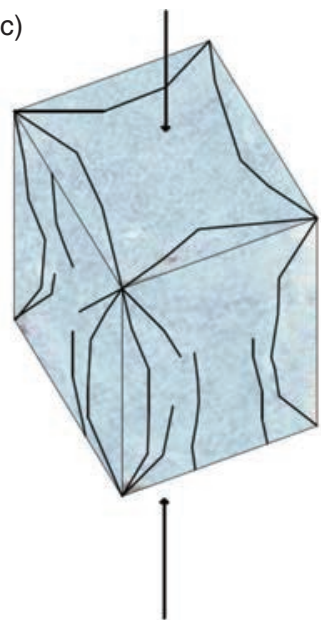

FIGURE 9. Diagrammatic view of the fractures developed in DG specimens under UCS conditions: splitting (a); shear (b); splitting and shear (c).

TABLE 4. $\mathrm{FST}_{\mathrm{x}}, \mathrm{FST}_{\mathrm{y}}, \mathrm{FST}_{\mathrm{z}}=$ flexural strength resistance $(\mathrm{MPa})$ recorded in the directions $\mathrm{X}, \mathrm{Y}$ and $\mathrm{Z}$, respectively; FST = average flexural strength $(\mathrm{MPa})$; and $\max /$ $\min =$ anisotropy FST strength ratio.

\begin{tabular}{lccccc}
\hline & $\mathbf{F S T}_{\mathbf{X}}$ & $\mathbf{F S T}_{\mathbf{Y}}$ & $\mathbf{F S T}_{\mathbf{Z}}$ & $\mathbf{F S T}$ & $\mathbf{m a x} / \mathbf{m i n}$ \\
\hline mean value & 9 & 13 & 15 & 12 & 1.6 \\
st.dev. & 1 & 1 & 2 & 2 & \\
\hline
\end{tabular}

$50 \%$ of the failure strength. Furthermore, samples showed the same quasi-elastic behavior along the two axes. The only difference appeared for the strain part, which was longer in the Z-direction than the $\mathrm{X}$-direction. Regarding the schematic representation of the failure orientations (Figure 9), the specimens broke in three different ways: splitting, shear, and splitting and shear. No difference was observed in the three directions analyzed and the difference in mode failure was probably due to the presence or absence of internal weak planes. Fractures were long, extended for the height of the sample and ran mainly parallel to the direction of loading. In the case of shear failure, fractures were oriented towards the inside of the sample. After the rupture, the sample presented an hourglass shape. Shear failure, i.e. complex conjugate failures (32), occurred along planes of weakness.

FST values were in line with the values reported for other building stones with similar textural and compositional characteristics (25). As was the case for UCS, no significant differences were noticed in the three directions, with the highest values being reached on the Z-axis (Table 4). According to the mean value of FST, DG corresponded to the "high" flexural strength class $(19,20,21)$. When compared to UCS, under FST conditions DG exhibited greater anisotropic behavior, as shown by the higher FST anisotropy ratio (1.6 vs. 1.1).

\section{DISCUSSION}

From a petrographic point of view, the existence of veins and crystals of differing sizes - thin and thick - means that DG is neither homogenous nor isotropic. Rather, it is somewhat heterogeneous. Its relative textural heterogeneity (veins and crystal size, areas of large crystals and areas of fine crystals) may be responsible for the anisotropy (albeit low) and may also be responsible for the non-optimal correlations. Regarding capillary behavior, even though the anisotropy is low, it seems to condition capillary absorption, as shown in Figure 7 where, based on the X-direction, DG would be expected to absorb more water after a certain amount of time. The low anisotropy, revealed by the UPV test, also seems to influence mechanical behavior, as shown by the slight differences in UCS and FST values in the three directions analyzed.

Correlations between petrophysical and mechanical properties are obtained (Figure 10). As expected, the lower the bulk density $\left(\rho_{\mathrm{b}}\right)$, the lower the mechanical strength. Regarding the relationship between open porosity $\left(\mathrm{p}_{\mathrm{o}}\right)$ and UPV (Figure 10a), it can be said that no strong correlation exists between the above-mentioned properties. Rather, there is only an inverse relationship: the lower the $\mathrm{p}_{\mathrm{o}}$, the higher the UPV propagation (33). In this case, the inverse correlation does seem strong and linear for UPV. This can be explained by the very low $\mathrm{p}_{\mathrm{o}}$ and by the low standard deviation that influences the very low variability among the values obtained. The low $\mathrm{p}_{\mathrm{o}}$ does not affect the UPV, as demonstrated by the very low values of correlation, considered as statistically insignificant. The non-linear relationship is in agreement with other authors, in particular for carbonate stones such as DG, with low $\mathrm{p}_{\mathrm{o}}(<2 \%)$ occurring where there is no significant correlation 

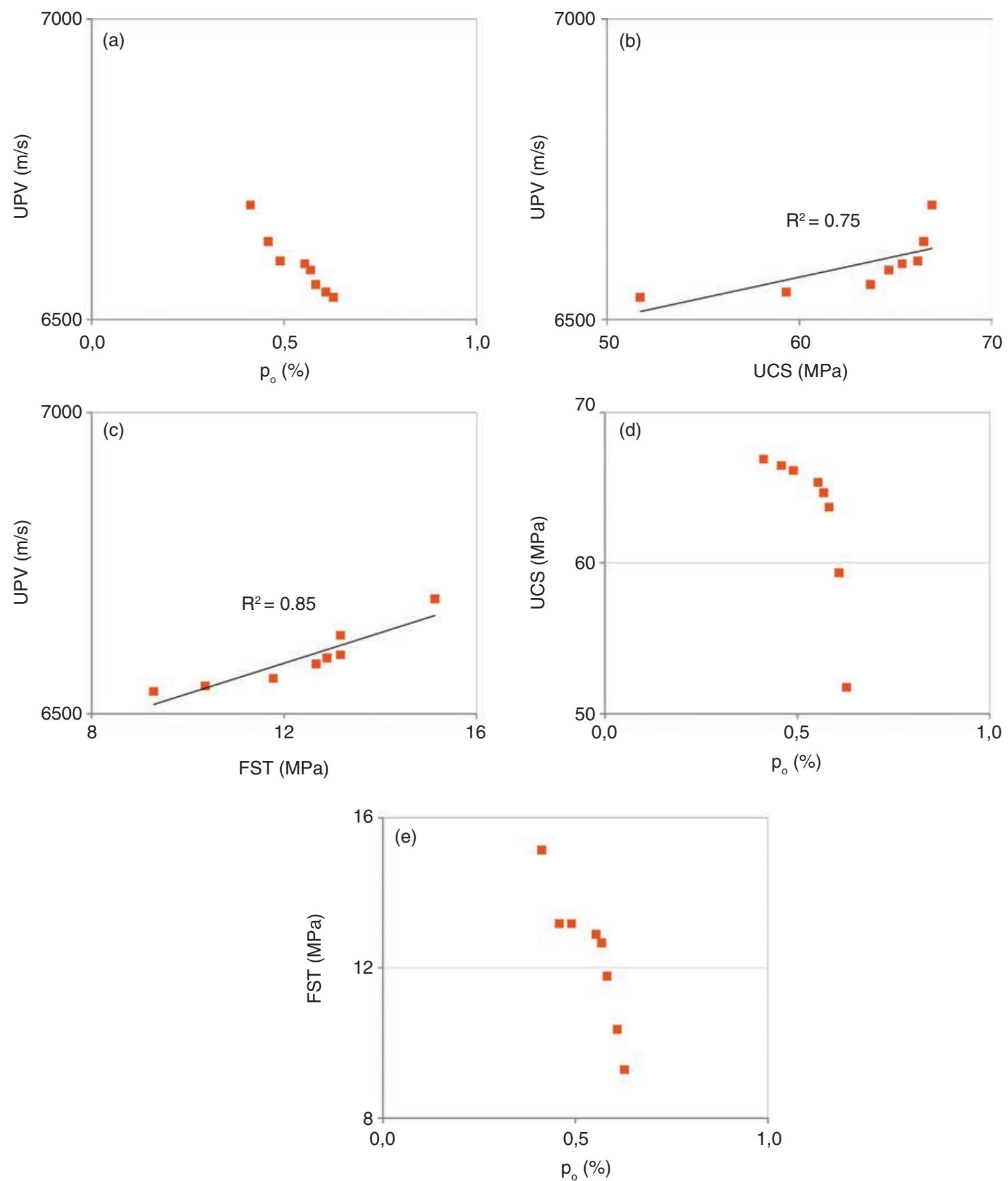

FIGURE 10. Relationships between physical and mechanical properties: UPV $v s . \rho_{b}(a), p_{o}$ (b), UCS (c), FST (d); $\rho_{b} v s$. UCS (e), FST (f); $p_{o} v s$. UCS (g), FST (h).

between $\mathrm{p}_{\mathrm{o}}$ and UPV (14). Even though there is not a linear correlation, it is possible to say that an inverse relationship exists between UPV and $\mathrm{p}_{0}$, as has also been proved by several authors in various lithological types $(34,35)$.

Weak relationships are also reached for $\mathrm{p}_{\mathrm{o}}$ when using UCS and FST (Figures 10d, 10e), with these possibly being weaker or non-linear. UCS and FST decrease as $p_{o}$ increases, as previously stated $(35,36)$. In the case of materials with very low porosity such as DG, no linear relationship exists even though UCS and FST decrease as $p_{o}$ increases (but without a linear correlation). This result is in contrast with the results of other researchers investigating lithotypes with low $p_{o}(35,37)$, but is in agreement with other researchers (16) who found that other factors, 

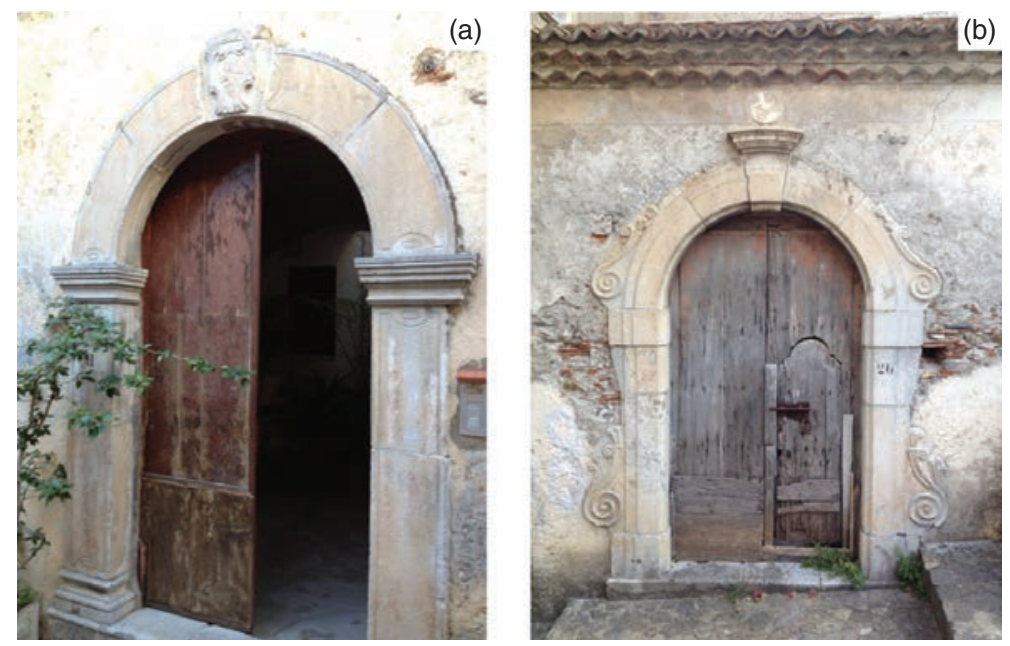

FIGURE 11. Examples of portals realized with Grisolia stone and affected by slight decay forms.

such as variable grain size and not $\mathrm{p}_{\mathrm{o}}$, seem to be the main causes of the variability of the strength of low porosity stones.

The correlation between UPV and UCS and FSTs is significant. There is a linear relationship between these properties (Figures 10b, 10c). As expected, the lower the UPV, the lower the UCS (21) and FST (38), and vice versa.

Analysis of decay on buildings constructed from DG reveals that decay is insignificant and almost absent. DG's open porosity, which conditions its permeability to fluids (14), combined with the presence of macropores instead of micropores that influence the stone's durability (39), play an important role with respect to the stone's resistance to decay factors. Fluids hardly circulate inside the stone because its low capillary coefficient - due to its low porosity - makes DG quite impermeable. These same internal features provide adequate protection against pollution ingress. DG's durability is also the result of its excellent mechanical properties and low structural anisotropy index. These make DG better able to endure $(39,40,41)$ the expansion and contraction induced by the mechanical stresses associated with external temperature variations or to endure internal salt-crystallization pressures (42).

Structural flaws, intrinsic discontinuities, surface deposits (Figure 11a), biological colonization and missing parts (Figure 11b) are the only forms of decay detected. Crumbling also occurs, although less frequently, and is associated with the structural instability of the entire building rather than with the mechanical strength of its building stone. Thus, restoration and conservation of DG require minimal work, consisting merely of cleaning and repair as necessary. Minor protection and consolidation are also recommended.

\section{CONCLUSIONS}

The complete petrophysical and mechanical characterization performed explains why Grisolia stone is a good natural building stone. Petrographically, DG has a heterogenous composition and texture. It is compact and petrographically quite isotropic. In fact, examining the oriented thin sections in the three directions analyzed does not reveal any significant preferential orientation. This is in agreement with the other tests performed where the corresponding anisotropy indices are very low. Similarly, in agreement with the low porosity values, the compactness index is high.

DG's petrographic characteristics, low porosity levels, predominant macroporosity, low water absorption capability, isotropic hydric behavior and high ultrasonic wave velocity stand as proof of the suitability of this stone for use in construction. The only recommended conservation techniques consist of removing stains and other surface deposits and repairing damaged stones.

Its high compressive strength also makes DG an ideal material for structural elements such as pilasters, portals, pedestals, staircases, flooring and baseboards, as well as for pavement cobbles and curbing. Its low strength anisotropy means it can be chiseled into shape and placed in constructions without having to pay attention to stone block orientation. Moreover, thanks to its durability, DG can be employed in both internal and external decorative and structural elements. The degree of conservation of historic buildings made from this material demonstrates that it is also resistant to most of the extrinsic factors that usually damage building stone, such as water, biological agents, salt and air pollution. For all these reasons, its use is recommended in both restoration and new building. 


\section{ACKNOWLEDGEMENTS}

This study was supported by "Programa Geomateriales 2 (S2013/MIT-2914)" and by "Fondi 5 per mille D.P.C.M. 23/04/2010".

\section{REFERENCES}

1. Forestieri, G.; Campolongo, A.; Ponte, M. (2016) La pietra e l'architettura. Analisi storica e materica del materiale lapideo nel territorio di Cosenza, in: D’Agostino S. (Ed.), Proc. $2^{\text {nd }}$ Int. Cong. History of Engineering 1, Naples, Italy, 213-222.

2. AA.VV. (2015) La pietra, il mestiere e l'arte del decorare. Storia della lavorazione della pietra nella provincia di Cosenza, Pellegrini Editore, Cosenza, (2015).

3. Amodio-Morelli, L.; Bonardi, G.; Colonna, V.; Dietrich, D.; Giunta, G.; Ippolito, F.; Liguori, V.; Lorenzoni, S.; Paglionico, A.; Perrone, V.; Piccarreta, G.; Russo, M.; Scandone, P.; Zanetti-Lorenzoni, E.; Zuppetta, A. (1976) The Calabrian-Peloritan Arc in the Apennine-Maghrebide orogen. Mem. Soc. Geol. It. 17, 1-60.

4. Damiani, A.V. (1970) Osservazioni geologiche in alcune tavolette del $\mathrm{F}^{\circ} 220$ della Calabria nord-occidentale. Parte I: Stratigrafia. Boll. Soc. Geol. It. 89, 65-80.

5. Mastandrea, A.; Perri, E.; Neri, C.; Russo, F. (2003) Conodont biostratigraphy of the Norian-Rhaetian deposits in the Northern Calabria. The Valle Corvino and Grisolia sections. B. Soc. Paleontol. I. 42 [1-2], 39-47.

6. Forestieri, G.; Ponte, M.; Francesco, A.M. de; Guido, A. (2015) Historical building stones of Cosenza Province, Calabria (Italy): properties and weathering, in Campanella L., Piccioli C. (Eds.), Proc. $6^{\text {th }}$ Int. Cong. Diagnosis, Conservation and Valorization of Cultural, Naples, Italy, 107-117.

7. Grandjacquet, C; Grandjacquet, M. J. (1962) Geologie de la zone Diamante-Verbicaro (Calabrie). Geol. Romana 1, 297-312.

8. EN 12407 (2007) Natural Stone Test Methods Petrographic Examination. Ente Nazionale Italiano di Unificazione, Milan, Italy.

9. Ordaz. J.; Esbert. R. (1985) Porosity and capillarity in some sandstone and dolomite monumental stone. 5th International Congress on Deterioration and Conservation of Stone, Lausane, 93-102.

10. EN 15886 (2010) Conservation of cultural property Test methods - Colour measurement of surfaces. Ente Nazionale Italiano di Unificazione, Milan, Italy.

11. EN 1925 (2000) Metodi di prova per pietre naturali Determinazione del coefficiente di assorbimento d'acqua per capillarità. Ente Nazionale Italiano di Unificazione, Milan, Italy.

12. EN 14579 (2005) Metodi di prova per pietre naturali Determinazione della velocità di propagazione del suono. Ente Nazionale Italiano di Unificazione, Milan, Italy.

13. EN 1926 (2000) Metodi di prova per pietre naturali Determinazione della resistenza a compressione. Ente Nazionale Italiano di Unificazione, Milan, Italy.

14. Siegesmund, S.; Dürrast, H. (2014) Physical and Mechanical Properties of Rocks. In: Siegesmund S., Snethlage R. (Eds.). Stone in Architecture. Properties, Durability 5th Edition, Springer, Berlin (2014). https://doi. org/10.1007/978-3-642-45155-3_3

15. Sebastián Pardo, E.; Cultrone, G.; Garibaldi, V.; Rodríguez Navarro, C.; De la Torre, M.J.; Valverde, I. (2008) The Sierra Elvira limestone: petrophysical features of a widespread Andalusian decorative material. Mater. Construcc. 58 [289-290], 51-63.

16. Guydader, J.; Denis, A. (1986) Propagation des ondes dans les roches anisotropes sous contrainte évaluation de la qualité des schistes ardoisiers. B. Eng. Geol. 33, 49-55.

17. Prikryl, R. (2001) Some microstructural aspects of strength variation in rocks. Int. J. Rock Mech. Min. 38, 671-682. https://doi.org/10.1016/S1365-1609(01)00031-4
18. EN 12372 (2001) Metodi di prova per pietre naturali Determinazione della resistenza a flessione sotto carico concentrato. Ente Nazionale Italiano di Unificazione, Milan, Italy.

19. Anon (1977) The description of rock masses for engineering purposes. Q. J. Eng. Geol. 10, 355-388. https://doi. org/10.1144/GSL.QJEG.1977.010.04.01

20. Anon (1979) Classification of rocks and soils for engineering geological mapping. Part 1 - Rock and soil materials. Bull. Int. Assoc. Eng. Geol. 19, 64-371.

21. Vasanelli, E.; Colangiuli, D.; Calia, A.; Sileo, M.; Aiello, M.A. (2015) Ultrasonic pulse velocity for the evaluation of physical and mechanical properties of a highly porous building limestone. Ultrasonics 60, 33-40. https://doi. org/10.1016/j.ultras.2015.02.010

22. Dunham, R.J. (1962) Classification of carbonate rocks according to depositional texture. In: Ham W.E. (Ed.), Classification of carbonate rocks. Am. Assoc. Petrol. Geol. Memo. 108-210.

23. Tucker, M.E. (2010) Geologia del sedimentario: rocce, strutture sedimentarie, ambienti deposizionali. Dario Flaccovio Editore, Palermo, $1^{\text {st }}$ Edition (2010).

24. Rodríguez-Navarro, C.; Sebastián Pardo, E.; Zezza, U.; Torre, M.J. de la; Cardell, C. (1991) Caracterización mineralógica y petrofísica de los materiales biocalcareníticos utilizados en la construcción de monumentos históricos de Granada. Boletín de la Sociedad Española de Mineralogía $14,25-26$.

25. García del Cura, M.A.; Benavente, D.; Bernabeu, A.; Fort, R.; La Iglesia, A.; Ordóñez, S. (2005) Las calizas microcristalinas como material de construcción: el caso del Gris Pulpis. Mater. Construcc. 55, 5-23. https://doi.org/10.3989/ mc.2005.v55.i277.177

26. Modestou, S.; Theodoridou, M.; Fournari, R.; Ioannou, I. (2015) Physico-mechanical properties and durability performance of natural building and decorative carbonate stones from Cyprus, Geological Society, London, Special Publications, 416, 145-162. https://doi.org/10.1144/ SP416.3.

27. Vasanelli, E.; Sileo, M.; Calia, A.; Aiello, M.A. (2013) Nondestructive Techniques to Assess Mechanical and Physical Properties of Soft Calcarenitic Stones. Procedia Chemistry 8, 35-44. https://doi.org/10.1016/j.proche.2013.03.006.

28. Mamillan, M. (1972) Connaissances actuelles pour mesurer le degré d'altération des pierres et l'efficacité des methodes de traitement. Proc. $1^{\text {st }}$ Int. Symp. Deterioration of building stones, La Rochelle (1972), 47-56.

29. Guerrero, M.A.; Vázquez, M.A.; Galán, E.; Zezza, F. (1989) The physical-mechanical properties and ultrasonic data as criteria for evaluation of calcareous stone decay. Proc. $1^{\text {st }}$ Int. Symp. La Conservazione dei Monumenti nel bacino del Mediterraneo, Bari, 309-312.

30. Krtolica, B.; Crnkovié, B. (1979) Ultrasonic testing of stone quality". Proc. $3^{\text {rd }}$ Int. Cong. Deterioration and Preservation of Stones, Venice, 219-225.

31. Gramberg, J.A (1989) Non-conventional View on Rock Mechanics and Fracture Mechanics. Commission of European Communities, Balkema, Rotterdam (1989).

32. Kelsall, P.C.; Watters, R.; Franzone, J.G. (1986) Engineering characterization of fissured, weathered dolerite and vesicular basalt. Proc. $27^{\text {th }}$ U.S. Symposium, 77-84.

33. Jermy, C.A.; Bell, F.G. (1998) Durability of some dolerites from South Africa. In: Moore, D.P., Hungr, O. (Eds.), Proc. 8th Inter. Cong. of IAEG, [4], Balkema, Vancouver, 2869- 2875

34. Sousa, L.M.O.; Suárez del Río, L.M.; Calleja, L.; Ruiz de Argandoña, V.G.; Rodríguez Rey, A. (2005) Influence of microfractures and porosity on the physico-mechanical properties and weathering of ornamental granites. Eng. Geol. 77, 153-168. https://doi.org/10.1016/j. enggeo.2004.10.001

35. Tuğrul, A.; Zarif, I.H. (1999) Correlation of mineralogical and textural characteristics with engineering properties of selected granitic rocks from Turkey. Eng. Geol. 51, 303-317. https://doi.org/10.1016/S0013-7952 (98)00071-4 
36. Bell, F.G.; Lindsay, P. (1999) The petrographic and geomechanical properties of some sandstones from the Newspaper Member of the Natal Group near Durban, South Africa. Eng. Geol. 53, 57-81. https://doi.org/10.1016/ S0013-7952(98)00081-7

37. Marini, P.; Bellopede, R. (2010) The mechanical resistance of saturated stones. Proc. Int. Congr. Global Stone, Alicante, Spain, 1-5.

38. Molina, E.; Benavente, D.; Sebastián, E.; Cultrone, G. (2015) The influence of rock fabric in the durability of two sandstones used in the Andalusian Architectural Heritage (Montoro and Ronda, Spain). Eng. Geol. 197, 67-81. https://doi.org/10.1016/j.enggeo.2015.08.009

39. Fort, R.; Fernández-Revuelta, B.; Varas, M.J., Álvarez de Buergo, M.; Taborda, M. (2008) Influence of anisotropy in the durability of Cretaceous dolostones from the region of Madrid against salt crystallization. Mater. Construcc. 58, 289-290.

40. Fort, R.; Varas, M.J.; Álvarez de Buergo, M.; Freire, D.M. (2011) Determination of anisotropy to enhance the durability of natural stone. J. Geophys. Eng. 8, [3], 132-144. https://doi.org/10.1088/1742-2132/8/3/S13

41. Fort, R.; Varas, M.J.; Álvarez de Buergo, M.; PerezMonserrat, E.M. (2015) Colmenar Limestone, Madrid, Spain: considerations for its nomination as a Global Heritage Stone Resource due to its long term durability. Geol. Soc. 407, 121-135. https://doi.org/10.1144/SP407.8

42. Winkler, E.M.; Singer, P.C. (1972) Crystallization pressure of salts in stone and concrete. Geol. Soc. Am. Bull. 83, 3509-3514 